\title{
Juridical Review of the Existence of Bengkok Land in Indonesian National Land Law
}

\author{
Rofi Wahanisa ${ }^{\text {la }}$, Aprila Niravita ${ }^{2 b}$, R. Benny Riyanto ${ }^{3 c}$ \\ ${ }^{1}$ Student of Doctoral Program of Law Science Universitas Diponegoro (UNDIP) Semarang, and lecturer in Faculty \\ of Law Universitas Negeri Semarang (UNNES), Indonesia \\ ${ }^{2}$ Department of Private and Commercial Law, Faculty of Law, UNNES, Semarang, Indonesia \\ ${ }^{3}$ Faculty of Law, Universitas Diponegoro, Semarang, Indonesia \\ rofiwahanisa@yahoo.com, ${ }^{\mathrm{b}}$ niravitanugroho@gmail.com
}

\begin{abstract}
The change of village into urban village (kelurahan) has an impact on the community, especially the people in the village area that experienced the change. The authority of the village as a unit of law society that has the right to regulate its own interests based on customs that have been going on for generations turns into administrative area of urban village (kelurahan) as part of district area under sub-district. The definite change is due to the loss of village privileges to manage their own interests, including land ownership of village land, and one of which is bengkok land. The term bengkok land, which refers to a plot of land (crop field) whose processing is carried out by village head who is in service for a certain period as a compensatory fee, is well known in Javanese community. Thus, the one working the land is a villager who is in service as a village officer. The status change leads to consequence in terms of the existence of bengkok land which is no longer used as "compensatory" fee for village officers.
\end{abstract}

Keywords—bengkok land; authority of the village; existence of bengkok land

\section{INTRODUCTION}

Land is an integral part in human life. It in fact carries very important meaning. It also becomes a highly important need as well as evidence of prosperity and someone's existence. One can be considered prosperous once she/he owns a lot of lands in considerably large area. Land can be owned and acquired by either individual or community/ social group, and it is regarded as "property" of the group or community. To the same extent, bengkok land comes as an example of such phenomenon.

The term bengkok land, which refers to a plot of land (field) in which the processing is carried out by village head during his term in office as compensatory fee, is well-known in Javanese society. Thus, the one working the land is a villager who is in service as a village officer. The land is not supposed to be owned by an individual, in this case the one in service. It is used communally by all villagers, and ownership of the land can pass from the former village officers to the new ones. It is essentially based on the principle that the land functions as "compensatory" fee given to village officers.

As the time passes, the terms of bengkok land have changed following land regulations. One of the underlying factors is the existence of regional autonomy controlling village government, in which a change occurs in terms of village officers' status. The status of village head changes into urban village head (lurah), and this becomes the underlying and concerned point in the current study. Village heads, who in the past were non-state officers, are now promoted to be Civil Servants (PNS). The promotion has impact on their wealth/ salary, as well.
Serving as village heads of non-state officers, they have authority to work the lands (fields) and take the crop yields as compensatory fee. After being promoted to be civil servants, they receive salary according to their rank and group. The change leads to logical consequence in terms of the existence of bengkok land which is no longer used as "compensatory" fee for village officers, including its general ownership especially in Semarang - whether the city government can make "claim" of bengkok land automatically with regard to the promotion given to village heads as civil servants and regional government officers of Semarang. Based on the description above, this paper aims at explaining the existence of bengkok land in national land law after the status change from village head to urban village head (lurah) who receives salary and no longer uses bengkok land as compensatory fee.

\section{RESULT AND DISCUSSION}

\section{A. Acquisition of Rights on Land}

Bengkok land in this paper refers to "compensatory" fee given to a village head as she/he does not receive salary from the state. The national land law, whose regulations are laid down in Basic Agrarian Law (UUPA) No. 5 of 1960, stipulates the acquisition hierarchy of rights on land in Basic Agrarian Law. Then, where is bengkok land placed within the regulations of the acquisition hierarchy?

Definitions of "acquisition" and "acquiring" can be interpreted physically, and the juridical meaning embraces public and civil aspects. Juridical acquisition is based on rights protected by law and generally giving authority to 
the owner to acquire land physically. Despite authorizing to acquire the land physically, there is a model whose physical acquisition is taken by other party. For instance, an owned land is leased to other party without rights. In this case, the land owner based on his/her juridical acquisition has right to demand the return of the land physically to him/her (Budi Harsono: 1997: 22) [1]

Therefore, within national land law it is known acquisition hierarchy of rights on land as follows (Budi Harsono:1997:22-23) [1]:

a. Right of Indonesia, as stipulated in Article 1 as the highest right of land tenure, embracing civil and public aspects;

b. Right of acquisition from the state as stipulated in Article 2, which only includes public aspect;

c. Communal title (hak ulayat) of customary law society as stipulated in Article 2, involving civil and public aspects;

d. Individual right which embraces civil aspect, consists of:

1) Rights on land as individual rights which are entirely derived from National Rights as stipulated in Article 16 and 53;

2) Endowment which becomes Property Right as stipulated in Article 49;

3) Land security right known as "Underwriting Right" as stipulated in Article 25,33,39 and 51.

With respect to the explanation of the hierarchy of land tenure right, bengkok land belongs to communal title of customary law society.

\section{B. Communal Title of Customary Law Society}

Definition of communal title can be found in Article 3 of Basic Agrarian Law (UUPA) which states:

"By considering terms in Article 1 and 2, communal title and the similar ones are implemented by customary law society. It needs to be applied in a way according to the Nation's and State's interests based on unity and following laws and the higher regulations."

According to Article 3 of Basic Agrarian Law above, "communal title and the similar ones" means:

The phrase above refers to what is known as "beschikkingrecht" in customary library. It can also be interpreted "it is not accepted in national life nowadays for a legal society to absolutely maintain and the content and implementation of their communal title as if they are separated from legal society and other regions in terms of the Nation as a unity."

The attitude also becomes the basic principle stipulated in Article 2 Basic Agrarian Law which states: "regarding the provision in Article 33 section (3) of the 1945 Constitution, land, water and space, including natural natural resources contained are managed by the State at the highest level as an organization of authority over all society."

The acquisition needs to be "utilized to achieve social prosperity in terms of happiness, prosperity, and freedom in society and independent, sovereign, fair, and prosperous legal state of Indonesia" (Article 2 section (3) of Basic Agrarian Law). Communal title, based on some experts, varies in its terms (Th. Sri Kartini \& Sri Sudaryatmi: 1996:21) [2]. Djojodiguno uses term Ancient Right (Hak Purba) while Soepomo defines it as Ownership Right (Hak Pertuanan). Hazairin then uses term Communal Right (Hak Ulayat), and in the Basic Agrarian Law the term Communal Title (Hak Ulayat) is used. Despite the existence of several definitions communal title/ ancient right/ ownership right/ communal right refers to right owned by a clan or village union (dorpenbond) or a village to acquire the entire land within ins region. [3] There are several characteristics of communal title (Th. Sri Kartini \& Sri Sudaryatmi: 1996:21) [2]:

1) Only the legal union as well as its members is allowed to freely utilize the land.

2) Foreigners is only allowed to utilize the land with permission from the union - no permission is considered violation.

3) Members of legal union is allowed to take benefits from the communal title for their family needs (somah/bayat)

4) The chief of the union is responsible for everything in the region, especially flouting actions which are considered as offenses.

5) Communal title cannot be released, transferred, exiled forever.

6) Communal title includes cropped land covered by individual right.

\section{Definition of Bengkok Land}

Bengkok land according to customary law refers to the right of occupational title owned by a village officer on the land granted by the village. This means that she/he may take the yields as long as she/he is in service (Th. Sri Kartini \& Sri Sudaryatmi: 1996: 30) [2]. The purpose of granting the right is to guarantee the village officer's salary.

The officer is allowed to work the land or lease it to the other party, but not allowed to sell or pawn it. If the officer is no longer in service or retired, the land is returned or belongs to authorized officer. The question then arises when the land is cropped - whether the yields are taken by the former or new officers. In order to provide the answers, there are two options (Th. Sri Kartini \& Sri Sudaryatmi: 1996:300) [2]:

a. If the crops are about to be harvested, former officer deserves to take the yields;

b. If the harvest still long, the new officer deserves to take some of the yields.

Term of bengkok land varies in some regions according to Ter Haar in his book entitled "Azas-Azas dan susunan Hukum Adat". [4]:
a. Saba na bolak
: Batak
b. Galung arajang
c. Dusun dati raja
: South Sulawesi
d. Bukti
: Ambon
e. Tanah Bengkok/tanah lungguh : Java
D. The Existence of Bengkok Land in National Land Law


Since the its issuance, Basic Agrarian Law (UUPA) becomes the elaboration of Article 33 section (3) of the 1945 Constitution stating that "the land, water, and all existing natural resources are owned by the State and used enormously for public prosperity (the 1945 Constitution from amendment result and amendment process of the 1945 Constitution, 1999: 26) [4]. State's authority to promote welfare for society as stated in Article 33 section (3) refers to "right to control the State" which embraces authority to:

1) Regulate and promote distribution, use, supply, and maintenance of land, water, and space.

2) Determine and regulate legal relationships between society and land, water, and space.

3) Determine and regulate legal relationships between society and legal actions related to land, water, and space (Harsono, 2005: 232) [1].

National land law in its implementation has proven to be able to provide support for development activities in all sectors that need land acquisition and use despite showing pitfall in terms of its content formulation and regulation features.

The pitfall has something to do with development realization during new order era that was based on erroneous interpretation of the principles and aims, and it leads to the recent consequences. In order to achieve legal State based on Pancasila, particularly dealing with just and civilized humanity, national land law needs to aim at protecting human rights as stipulated in TAP MPR No. IX/MPR/2001 November 9 ${ }^{\text {th }}$, 2001 on Agrarian Reform and Natural Resource Management which states "resources/ natural resources including land, water, and space as well as natural resources contained given by the Almighty to Indonesia become the national treasure that must be gratefully appreciated and therefore has to be utilized and managed optimally for future generations in order to create just and prosperous society".

Bengkok land, as part of village land, has been utilized as compensatory fee for village officers. In this case, village head and other officers have right over the granted land to live their family life by working the land, and the yields are adjusted to their positions. When one no longer serves as village officer, the land will belong to village. Thus, it can be summarized that bengkok land has the following characteristics:

1) It becomes part of lands owned by village.

2) It is granted to villagers serving as village officers.

3) The grant is temporary as long as one is serving as village officer.

4) The grant functions as compensatory fee to live his/her life. (Ramelan, 1999: 111) [6]

Due to the issuance of Law No. 5 of 1979 on Village Government and promoting Village officers to Civil Servants, bengkok land belongs to regional government following the fact that autonomy lying in regional government (regency/city) had been replaced with Law No. 22 of 1999 on regional government, which was later followed by several changes from the previous one into Law No. 32 of 2004 on regional government, Law No. 8 of 2005 on the Establishment of Regulation in Lieu of
Law No. 3 of 2005 on the Amendment of Law No. 32 of 2004 from regional government to Law, then Law No. 12 of 2008 on the Second Amendment of Law No. 32 of 2004 on regional government.

Observing the authority resulted from bengkok land, it appears that villagers have autonomy in terms of their independency in managing and solving problems dealing with the land located within their area. Independency in managing the land is also supported with discussion mechanism which functions as a forum to involve villagers before village head takes important decision, especially the one regarding the land. Hence, it is not surprising decision taken from such mechanism creates no conflicts or problems as society is involved in the process of decision making.

Bengkok land as part of village land is also generally utilized to build public facilities such as community health center (Puskesmas), sport center, worship place, village office, and cemetery. Those social facilities can be achieved trough discussion attended by public figures who proposing the facilities, the consensus is then forwarded to subdistrict and finally granted by regional government.

In addition, bengkok land can serve function as a source of village income according to the Regulation from the Minister of Home Affairs No. 1 of 1982 on Income Sources and Resources of Village as well as Their Management and Supervision. In Article 3 it is stated that village resources comprise of:

1. Granted land, including bengkok land

2. Public bathing place managed by village

3. Village market

4. Tourism place managed by village

5. Buildings owned by village

6. Other resources owned by village government

The implementation of Instruction from the Minister of Home Affairs No. 26 of 1992 on Status Change of Bengkok Land as village treasure leads to the fact it is managed and supervised as granted land owned by village. The legal consequence of the change is that the granted land becomes one of the income sources for village in which the income comes from public bathing place, village market, tourism place, buildings managed by village, other resources. The income is then used entirely for government affairs, development, and social needs, and it is supervised by regent, mayor, or appointed official. Related to Law No. 12 of 2008 on the Second Amendment of Law No. 32 of 2003 concerning regional government and the regulation giving complete autonomy for regency/ city government to manage its home affairs including income source, asset in the form of bengkok land located in its territory needs to be considered and managed in order to increase locally-generated income (PAD) generally and specifically raise village income.

Management of bengkok lands is carried out by village head and village officers so that some attempts are needed to organize and utilize the lands according to the regulations. In this case, a term "bondo deso" is used to refer to bengkok land of village officer which is used for 
public facilities and disallowed to be given to other parties except that it is used in development project.

Function of bengkok land as village resources for Regional Government becomes significant following the establishment of Law No. 5 of 1979 on Village Government and the beginning of regional autonomy in Law No. 22 of 1999 on Regional Government.

Juridical acquisition of a land is based on right protected by law and generally giving authority to to the owner to acquire land physically. Despite authorizing to acquire the land physically, there is a model whose physical acquisition is taken by other party. For instance, the owned land is leased to other party, and the tenant acquires the land physically - or the land is acquired by other party physically in inappropriate rights.

The land owner according to his/her juridical acquisition has right to demand the return of the land physically to him/her. National land law is a realization of Article 33 section 3 of the 1945 Constitution which is the legal principle of land or agrarian law. Thus, it is obvious that authority given to the State according to the statement in Basic Agrarian Law (UUPA) corresponds to the aims of UUPA which consist of (Budi Harsono, 1997: 102) [1]:

1) Laying down principles for the formulation of national agrarian law which is a means to provide prosperity, happiness, and justice for the Nation and society, particularly agrarian society in order to create just and prosperous society;

2) Laying down principles to achieve unity and simplicity in land law;

3) Laying down principles to give legal assurance in terms of land rights for the whole society.

Policy aspects needs to be overridden by central government in order to create national land policies. The operational realization of those policies, however, can be given to regional government autonomously. Operational activities that contain policy aspects and have national impacts are delegated to regional government through deconcentration. Consequently, land affair autonomy (decentralization) is carried out coincidentally with deconcentration according to clear authority and job distribution.

From the establishment of Law No. 22 of 1999 on Regional Government to the amendment of Law No. 12 of 2008 on the second amendment of Law No. 32 of 2004 on regional government who also regulates principles of granting autonomy for regency or city as autonomous region, regional autonomy based on the law is defined as autonomous authority to regulate and manage local public's affairs according to their own aspirations following the legislation within the Unitary State of the Republic of Indonesia.

Then, government sectors that need to be embraced by regency or city consist of public works, investment, environment, land, cooperation, and manpower. Policy of autonomy extension on regency and city including land sector needs improvement in terms of national land law. In fact, while national land law is still under the authority of the State, the grant of autonomy is limited to its partial or complete realization. For the sake of maintaining national affairs and continuity of land function as the main element of national unity, central government needs to establish general policies and limitation for the autonomous authority in land sector.

However, continuous guidance and supervision are needed as well in implementing national land law, including providing and training human resources as the executors. Land policies from central government implemented and developed by regional government need to be based on the higher policies.

Regarding the existence of regional autonomy applied in every regency or city, the government has authority to manage regional assets to increase regional income. One of the assets utilized by regional government to raise regional income is bengkok land. Bengkok land in Basic Agrarian Law No. 5 of 1960 is stipulated in conversion terms in Article VI which turns to be right of usage stating:

"Rights over land which give authority as mentioned or closely in Article 41 section (1)". As mentioned as follows, from the establishment, this Law becomes the right of usage in Article 41 section (1), which gives authority and responsibility as hold by the owner from the establishment of this Law as long as it does not contradict life and terms of this Law."

In Article 41 section (1) of Basic Agrarian Law, right of usage refers to "right to use and/ or take outcome of the lands acquired by the State or other parties who give authority and responsibility stipulated in grant terms issued by authorized officials in agreement with the land owners which is neither leasing nor land processing agreement as long as it does not contradict life and terms of this Law." Therefore, according to Article 41 section (2), right of usage can be given in several conditions:

a. Within particular period or as long as the land is used for particular purpose.

b. Freely with any service payment.

From the issuance of the Law above, clear general regulations exist. Regarding the fact that the use of bengkok land has become right of usage and the outcome is managed by the State, it can be inferred that bengkok land based on Law No. 5 of 1960 on Basic Regulations of Agrarian Principles no longer exists, and its right of usage belongs to the State.

Sejak mulai berlakunya undang-undang tersebut sudah ada pengaturan yang umum dan jelas tentang tanah bengkok. Hal mana tanah bengkok yang telah menjadi Hak Pakai dalam penggunaannya dan pemungutan hasilnya merupakan tanah yang dikuasai oleh Negara, maka dapat diambil pengertian bahwa keberadaan tanah bengkok berdasar Undang-undang Nomor 5 Tahun 1960 tentang 1960 tentang Peraturan Dasar Pokok-pokok Agraria sejak diberlakukannya sudah tidak ada dan telah menjadi Hak Pakai yang merupakan tanah yang dikuasai oleh Negara.

\section{CONCLUSION}

The existence of bengkok land in many regencies/ cities gradually disappears due to various interests. It is realized as a result of development and advancement in which 
bengkok land, which was a land given to village head or village officers as "compensatory fee" needs to be converted to individual right regarding government regulations and policies of regional autonomy. As communal ownership seems to be lack of legal certainty, it appears that there are attempts to change bengkok land into lands with individual status such as land with freehold (HM). Moreover, due to the existence of regional autonomy, asset inventory including the existence of bengkok land is managed not only by one agency but also by agencies of city government. Consequently, responsibilities can be easily "handed over" once problems related to the land occur.

Transition of bengkok land to be land with individual right is carried out through mechanism stipulated in the regulations of the Minister of Agrarian Affairs/ Chief of Land Agency which starts from releasing bengkok land to the State. Bengkok land, in fact, still exists in accordance with communal title on land as stipulated in Article 3 of Basic Agrarian Law. With respect to the fact above, regency/ city government needs to take several attempts. First, inventory on the existence of bengkok lands located in the region. According to the applied regional regulations, bengkok land can be one of the regional assets whose benefits can be received communally. Second, it needs regulations on the existence of bengkok land managed through regional regulations (Perda) as the characteristics and the existence of bengkok land vary in terms of the terms or usage.

\section{REFERENCES}

[1] Harsono, B. (1975). Hukum Agraria Indonesia. Djambatan

[2] Sukirno, S. S., \& Kartini, T. H. Sri. 2000. Beberapa Aspek Hukum Adar. Badan Penerbit UNDIP. Semarang.

[3] Imam, S. (1981). Hukum Adat Sketsa Asas. Yogyakarta, Liberty.

[4] Muhammad, B. (1986). Asas-asas hukum adat:(suatu pengantar). Pradnya Paramita.

[5] UUD 1945 Hasil Amandemen \& proses Amandemen UUD 1945, 1999

[6] Kumalasari, Y. (2016). Perlindungan Hukum Terhadap Pihak Pembeli Beritikad Baik Dalam Jual Beli Tanah Bengkok. Kumpulan Jurnal Mahasiswa Fakultas Hukum. 